\title{
KEPUASAN KERJA DAN MASA KERJA SEBAGAI PREDIKTOR KOM ITMEN ORGANISASI PADA KARYAWAN PT ROYAL KORINDAH DI PURBALINGGA
}

\author{
Purida Kingkin ${ }^{1)}$, Haryanto Fadholan Rosyid ${ }^{2)}$ \& Ruseno Arjanggi ${ }^{1)}$ \\ 1) Fakultas Psikologi Universitas Islam Sultan Agung Semarang \\ 2) FakultasPsikologi Universitas Gajah M ada Yogyakarta
}

\begin{abstract}
This study aimed to verify empirically the relationship between job satisfaction and years of service with the commitment of the organization, know how big contribution of job satisfaction, organizational commitment and know how big contribution of years of service with the commitment of the organization. The population in this study as part of its permanent employees with monthly samples of 50 department employees and use of purposive sampling quota. This research data collection methods using scales. There are three hypotheses. Major hypothesis of this study is there a connection between job satisfaction and years of service with the organization's commitment to the employees of Royal Korindah in Purbalingga. M inor first hypothesis of this study is there a positive relationship between job satisfaction, organizational commitment to the employees of Royal Korindah in Purbalingga. M inor second hypothesis of this study is there a relationship between years of service with the organization's commitment to the employees of Royal Korindah in Purbalingga. Conclusion The results indicate that there is a significant relationship between job satisfaction and years of service with the organization's commitment to the employees of Royal Korindah in Purbalingga, there was a significant positive relationship between job satisfaction and organizational commitment and there wass a significant positive relationship between years of service with the commitment of the organization.
\end{abstract}

Keywords: Organizational Commitment, Job Satisfaction and Work Period.

\section{Pendahuluan}

Organisasi merupakan perangkat sosial dan teknologi yang terdiri dari faktorfaktor manusia dan fisik. Dibantu oleh penerapan teknologi, manusia melakukan fungsi atau tugas yang menuntun kepada tercapainya sasaran yang ditentukan secara rasional. Manusia di dalam suatu organisasi dipandang sebagai sumber daya, artinya sumber daya atau penggerak dari suatu organisasi. Roda organisasi sangat tergantung pada perilaku-perilaku manusia yang bekerja di dalamnya. 
Komitmen anggota organisasi menjadi hal penting bagi sebuah organisasi dalam menciptakan kelangsungan hidup sebuah organisasi apapun bentuk organisasinya. Komitmen menunjukkan hasrat karyawan sebuah perusahaan untuk tetap tinggal dan bekerja serta mengabdikan diri bagi perusahaan.

Pentingnya komitmen yang tinggi dari karyawan bagi suatu perusahaan dijelaskan oleh Mathieu dan Zajac (Murtiningtyas, 2007) yang menyatakan bahwa dengan adanya komitmen yang tinggi dari karyawan maka perusahaan akan mendapat dampak positif. Dampak positif tersebut antara lain meningkatnya produktifitas, kualitas kerja dan kepuasan kerja karyawan serta menurunnya tingkat keterlambatan, absensi dan turn over.

Greenberg (Martini dan Rostiana, 2003) menjelaskan bahwa komitmen organisasi diperlukan sebagai salah satu indikator kinerja karyawan. Karyawan dengan komitmen yang tinggi dapat diharapkan akan memperlihatkan kinerja yang optimal. Temaluru (Martini dan Rostiana, 2003) berpendapat bahwa organisasi memiliki hubungan positif dengan kepuasan kerja. Sementara Angie, Perry dan Salancik (M artini dan Rostiana, 2003) menjelaskan bahwa komitmen organisasi juga dapat menggambarkan tingkat produktifitas, memprediksi tingkat keluar masuknya karyawan dan tingkat absensi karyawan dalam suatu perusahaan. Indikasi adanya komitmen yang rendah dalam perusahaan Royal Korindah adalah seringnya karyawan meminta ijin keluar kantor pada jam kerja, hal tersebut menyebabkan produktifitas kerja menurun, dimana seorang karyawan seharusnya dapat menyelesaikan pekerjaannya dengan hasil yang sesuai target tetapi karena seringnya ijin membuat hasil kerjanya kurang dan menyebabkan penurunan produktifitas.

Banyak hal yang mendorong terciptanya komitmen organisasi, di antaranya kepuasan-kepuasan yang diperoleh di dalam organisasi atau selama mereka bekerja. Kepuasan akan pembayaran yang diberikan perusahaan, kepuasan kondisi kerja secara mental terkait dengan tantangan pekerjaan yang dihadapi, sikap atasan dan pengawasan yang ada, hubungan dengan sesama rekan kerja yang merupakan faktorfaktor penentu komitmen organisasi. Komitmen organisasi yang tinggi tidak bisa muncul dengan sendirinya. Karena ada banyak faktor yang berperan di dalamnya seperti yang dinyatakan oleh Harrison dan Hubard (Febriani, 2004) yaitu kepuasan kerja, kepercayaan terhadap pemimpin, keikutsertaan pegawai dalam mengambil keputusan, usia, perilaku pimpinan dan masa kerja. 
Berdasarkan apa yang telah dikemukakan sebelumnya bahwa keluhan pada pekerjaan, tingkat ketidakhadiran yang tinggi, seringnya terjadi kesalahan atau kecelakaan dalam tugas, pemogokan maupun keinginan dan perilaku pindah kerja ke perusahaan lain merupakan indikasi terhadap masalah dalam diri karyawan yang berkenaan dengan komitmen.

Dari fenomena tersebut di atas, menimbulkan pertanyaan dalam diri peneliti, apakah kepuasan kerja berkaitan dengan komitmen organisasi pada karyawan PT Royal Korindah? Berdasarkan uraian di atas, maka penulis ingin mengetahui apakah ada hubungan antara kepuasan kerja dengan komitmen organisasi.

Doraisamy (2007) mendefinisikan komitmen adalah perjanjian (persetujuan) untuk melakukan sesuatu yang menjadikan pihak terkait berusaha untuk melaksanakannya. Komitmen terhadap organisasi disebut juga sebagai daya kekuatan hubungan, pengenalan dan penglibatan diri seseorang terhadap organisasi.

Luthans (1998) mengartikan komitmen organisasi sebagai sikap kesetiaan pegawai terhadap organisasinya yang merupakan proses terus-menerus yang bertujuan untuk mengekspresikan perhatian terhadap organisasinya yang mencerminkan kesuksesan dan kesejahteraan.

Shirbagi (2007) menjelaskan komitmen organisasi adalah sikap yang penting dalam menilai karyawan, perhatian karyawan untuk berhenti atau memberikan konstribusi secara keseluruhan kepada organisasi. Seniati (2006, h. 89) menyatakan komitmen organisasi adalah keterikatan karyawan pada organisasi dimana karyawan bekerja.

Luthans (1995) berpendapat bahwa komitmen organisasi memiliki tiga aspek, yaitu: (a). Keinginan untuk tetap menjadi anggota organisasi; (b). Kesediaan untuk bekerja semaksimal mungkin demi kepentingan perusahaan; (c). Kepercayaan serta penerimaan terhadap nilai-nilai dan tujuan perusahaan.

Seniati (2006, h. 90) mengemukakan faktor-faktor yang mempengaruhi komitmen organisasi adalah Faktor pribadi yang terdiri dari masa kerja dan trait kepribadian, dan faktor lingkungan yang terdiri dari iklim psikologis dan kepuasan kerja.

As'ad (2004) mendefinisikan kepuasan kerja sebagai perasaan seseorang terhadap pekerjaan. Ini berarti bahwa konsepsi kepuasan kerja semacam ini melihat kepuasan kerja itu sebagai hasil interaksi manusia dengan lingkungan kerjanya. Jadi determinasi kepuasan kerja menurut batasan ini meliputi perbedaan individu maupun 
situasi lingkungan pekerjaan. Disamping itu perasaan orang terhadap perusahaan tentulah sekaligus merupakan refleksi dari sikapnya terhadap pekerjaan.

As'ad (2004) mengemukakan aspek-aspek kepuasan kerja sebagai berikut: (a). Aspek Psikologik, yaitu berhubungan dengan kejiwaan karyawan yang meliputi minat, ketentraman dalam kerja, sikap terhadap kerja, bakat dan ketrampilan; (b). Aspek Sosial yaitu aspek yang berhubungan dengan interaksi sosial baik antara sesama karyawan, dengan atasannya, maupun karyawan yang berbeda jenis pekerjaannya; (c). Aspek fisik, yaitu aspek yang berhubungan dengan kondisi fisik lingkungan kerja, pengaturan waktu kerja, perlengkapan kerja dan kondisi kesehatan karyawan; (d). Aspek finansial yaitu aspek yang berhubungan dengan kesejahteraan karyawan yang meliputi sistem dan basarnya gaji, jaminan sosial, fasilitas, promosi dan macam-macam tunjangan.

Simamora (1995) menyebutkan bahwa senioritas atau lama bekerja seorang karyawan adalah lamanya waktu seorang karyawan telah berdinas dalan perusahaan divisi, departemen atau pekerjaan. Mugihardjo (dalam Setyowati, 2005) menjelaskan masa kerja atau sering disebut senioritas adalah sejumlah masa bekerja karyawan secara terus-menerus dalam suatu organisasi. Seorang karyawan senior mampu menyesuaikan diri berdasarkan pengalaman-pengalaman yang diperoleh. Hal ini disebabkan para karyawan tersebut mampu beradaptasi dengan pekerjaannya (Davis, 1994).

Nitisemito (dalam Oktafiyani, 2009) mendefinisikan senioritas atau masa kerja adalah lamanya seorang karyawan menyumbangkan tenaganya pada perusahaan tertentu. Sejauh mana tenaga kerja dapat mencapai hasil yang memuaskan dalam bekerja tergantung dari kemampuan, kecakapan dan ketrampilan tertentu agar dapat melaksanakan pekerjaanyan dengan baik. Masa kerja merupakan hasil penyerapan dari berbagai aktivitas manusia, sehingga mampu menumbuhkan keterampilan yang muncul secara otomatis dalam tindakan yang dilakukan karyawan dalam menyelesaikan pekerjaan. Masa kerja seseorang berkaitan dengan pengalaman kerjanya.

Karyawan yang telah lama bekerja pada perusahaan tertentu telah mempunyai berbagai pengalaman yang berkaitan dengan bidangnya masing-masing, dalam pelaksanakan kerja sehari-harinya karyawan menerima berbagai input mengenai pelaksanaan kerja dan berusaha untuk memecahkan berbagai persoalan yang timbul, sehingga dalam segala hal kehidupan karyawan menerima informasi atau 
sebagai pelaku segala kegiatan yang mereka lakukan. Maka karyawan tersebut telah memperoleh pengalaman kerja

Berdasarkan kajian literatur yang dilakukan oleh peneliti maka peneliti mengajukan hipotesis dalam penelitian ini. Hipotesis mayor yang diajukan dalam penelitian ini adalah : “Ada hubungan antara kepuasan kerja dan masa kerja dengan komitmen organisasi pada karyawan. Komitmen organisasi dapat diperoleh dengan didasari kepuasan kerja pada diri karyawan dan memiliki masa kerja yang lama". Sedangkan hipotesis minor yang diajukan dalam penelitian ini adalah : (a). Ada hubungan positif antara kepuasan kerja dengan komitmen organisasi. Hipotesis tersebut diartikan bahwa semakin tinggi kepuasan kerja maka semakin tinggi pula komitmen organisasinya, sebaliknya semakin rendah kepuasan kerja maka semakin rendah pula komitmen organisasinya; (b). Ada hubungan positif antara masa kerja dengan komitmen organisasi. Hipotesis tersebut diartikan bahwa semakin lama masa kerja maka semakin tinggi pula komitmen organisasinya, sebaliknya semakin rendah masa kerja maka semakin rendah pula komitmen organisasinya.

\section{Metode}

Sampel dalam penelitian ini adalah sebagian dari karyawan tetap Departemen Bulanan PT Royal Korindah dengan jumlah sampel try-out (uji coba alat ukur) adalah 60 karyawan, sedangkan sampel penelitian adalah 45 karyawan. Teknik pengambilan sampel digunakan untuk mengambil sampel dalam penelitian. Teknik sampling yang digunakan dalam penelitian ini adalah quota purposive sampling yaitu jumlah pengambilan sampel ditentukan terlebih dulu oleh peneliti dan dipilih secara khusus berdasarkan tujuan tertentu (Arikunto, 2002). Metode pengumpulan data pada penelitian ini menggunakan skala. Alasan penulis menggunakan metode skala adalah karena skala dapat menggambarkan aspek kepribadian individu, dapat memancing jawaban yang merupakan refleksi dari keadaan diri subjek yang tidak disadari (Azwar, 2003).

Aitem skala uji coba komitmen organisasi berjumlah 30 aitem. Hasil uji coba skala komitmen organisasi dari 30 aitem terdapat 22 aitem yang memiliki daya beda aitem tinggi dan 8 aitem yang berdaya beda rendah. Koefisien daya beda untuk aitem yang memiliki daya beda tinggi berkisar antara 0,307 - 0,726 dengan taraf signifikansi 0,05 .

Hasil uji coba daya beda aitem skala kepuasan kerja menunjukkan dari 40 aitem terdapat 27 aitem yang berdaya beda tinggi dan 13 aitem yang berdaya beda 
rendah. Koefisien daya beda aitem pada skala ini adalah berkisar antara 0,301 - 0,745 dengan taraf signifikansi $5 \%$.

\section{Hasil dan Pembahasan}

Hasil analisis estimasi normalitas menunjukkan bahwa data yang diperoleh untuk variabel komitmen organisasi memperoleh nilai Z-score $=1,282$ dengan $p=0,075$ sehingga dapat disimpulkan $(p>0,05)(0,075>0,05)$. Hasil tersebut menunjukkan bahwa sebaran data komitmen organisasi memiliki distribusi normal. Hasil analisis terhadap variabel kepuasan kerja diperoleh Z-score $=1,133$ dengan taraf signifikansi $=0,153$ sehingga dapat disimpulkan bahwa $(p>0,05)(0,153>0,05)$. Hasil tersebut menunjukkan bahwa sebaran data kepuasan kerja adalah normal. Hasil analisis terhadap variabel masa kerja diperoleh Z-score $=1,154$ dengan taraf signifikansi $=0,139$ sehingga dapat disimpulkan bahwa $(p>0,05)(0,139>0,05)$. Hasil tersebut menunjukkan bahwa sebaran data masa kerja adalah normal.

Berdasarkan hasil uji linieritas yang dilakukan antara variabel kepuasan kerja dengan komitmen organisasi diperoleh nilai Flinier $=90,587$ dengan $p=0,000 \quad(p>0,05)$. Hasil tersebut menunjukkan bahwa distribusi skala kepuasan kerja dan komitmen organisasi dalam penelitian ini linier atau kedua variabel membentuk garis lurus. Estimasi linieritas pada distribusi skala masa kerja dengan komitmen organsasi diperoleh Flinier $=3,764$ dengan $p=0,059(p>0,05)$. Hasil tersebut menunjukkan bahwa distribusi skala masa kerja dan komitmen organisasi dalam penelitian ini tidak linier atau kedua variabel tidak membentuk garis lurus. Hadi (2001) menyatakan langkahlangkah alternatif jika tidak linier adalah sebagai berikut: (a). Mengganti analisis parametik yang direncanakan dengan model analisis lain, umumnya analisis nonparametik yang setara; (b). Tetap menggunakan model analisis yang direncanakan tetapi membuat interpretasi yang longgar, ini hanya menunjukkan kehati-hatian yang besar. Kehati-hatian mengarah kepada lebih baik menyatakan tidak ada hubungan (korelasi) sekiranya hasil ujinya nyaris pada ambang batas penerimaan dan penolakan hipotesis. Aturannya adalah dengan melipatduakan besar peluang galat alpha $p$ (probability of alpha error $\mathrm{p}$ ) dari hasil ujinya atau menyatakan kesimpulan adanya perbedaan atau korelasi belum konklusif, tetapi baru indikatif yang masih memerlukan konfirmasi dalam penelitian-penelitian selanjutnya.

Berdasarkan estimasi yang telah dilakukan terhadap uji multikolinieritas diketahui bahawa nilai tolerance skala konsep diri dan persepsi tehadap metode 
mengajar guru adalah $1,000(>0,01)$, nilai VIF yang terdapat dalam skala konsep diri dan skala persepsi terhadap metode mengajar guru adalah $1,000(<10)$. Hal ini menunjukkan bahwa tidak terjadi multikolonieritas antara variabel-variabel bebas pada penelitian tersebut. Dari hasil perhitungan uji homosedastisitas dapat diketahui bahwa tidak terdapat pola tertentu yang jelas, serta titik-titik menyebar di atas dan di bawah angka 10 pada sumbu Y yang artinya bahwa terjadi homosedastisitas.

Berdasarkan uji korelasi yang telah dilakukan antara kepuasan kerja dan masa kerja dengan teknik analisis regresi maka diperoleh $\mathrm{R}=0,841$ dan Fhitung $=50,840$ dengan $p=0,000$ ( $p \varangle 0,01$ ). Hasil tersebut menunjukkan bahwa ada hubungan yang signifikan antara kepuasan kerja dan masa kerja dengan komitmen organisasi. Hasil uji korelasi yang telah dilakukan menghasilkan sumbangan efektif $70,8 \%$.

Berdasarkan uji korelasi parsial yang telah dilakukan antara variabel kepuasan kerja dengan komitmen organisasi dan melakukan kontrol terhadap variabel masa kerja diperoleh $r_{y 1-2}=0,826$ dengan $p=0,000(p<0,01)$. Hasil tersebut menunjukkan bahwa ada hubungan positif yang signifikan antara kepuasan kerja dengan komitmen organisasi. Hasil uji korelasi parsial yang telah dilakukan menghasilkan sumbangan efektif $65,9 \%$. Berdasarkan hasil uji korelasi parsial yang telah dilakukan antara masa kerja dengan komitmen organisasi maka diperoleh $r_{y 1-2}=0,303$ dengan $p=0,046$ $(p<0,05)$. Hasil tersebut menunjukkan bahwa ada hubungan positif yang signifikan antara masa kerja dengan komitmen organisasi. Hasil uji korelasi parsial yang telah dilakukan menghasilkan sumbangan efektif 4,9\%.

Hipotesis pada penelitian ini ada tiga, hipotesis mayor ada hubungan antara kepuasan kerja dan masa kerja dengan komitmen organisasi. Hipotesis minor pertama ada hubungan positif antara kepuasan kerja dengan komitmen organisasi. Hipotesis minor kedua ada hubungan positif antara masa kerja dengan komitmen organisasi.

Hipotesis mayor pada penelitian ini adalah hubungan antara kepuasan kerja, masa kerja dengan komitmen organisasi. Hasil analisis menunjukkan ada hubungan poaitif signifikan antara kepuasan kerja, masa kerja dengan komitmen organisasi karyawan PT. Royal Korindah Purbalingga dengan $R=0,841$ dan Fhitung =50,840 dan $p=0,000(p \varangle 0,001)$ artinya bahwa semakin tinggi kepuasan kerja dan masa kerja karyawan maka semakin tinggi pula komitmen organisasi pada karyawan. Secara keseluruhan sumbangan efektif variabel kepuasan kerja adalah 65,9\% dan sumbangan efektif variabel masa kerja adalah 4,9\%. 
Hasil tersebut senada dengan yang dikatakan oleh Aamodt (2004) bahwa karyawan yang puas akan berkomitmen terhadap organisasi. Karyawan yang puas dan berkomitmen akan menetap di organisasinya dan bekerja dengan baik. Berdasarkan hasil penelitan rata-rata karyawan bagian Departemen Bulanan memiliki kepuasan kerja, masa kerja dan komitmen organisasi yang tinggi. Kepuasan yang tinggi dikalangan karyawan disebabkan perusahaan telah memenuhi kebutuhan dan kesejahteraan karyawan. Komitmen merupakan kondisi psikologis yang mencirikan hubungan antara karyawan dengan organisasi dan memiliki implikasi bagi keputusan individu untuk tetap berada atau meninggalkan organisasi (Sulianti, 2009).

Komitmen keorganisasian karyawan dapat dipengaruhi oleh banyak faktor. Kepuasan kerja dan masa kerja karyawan merupakan salah satu faktor yang mempengaruhi. Sebagaimana penelitian yang dilakukan oleh Pratiwi $(2006$, h. 2) yang menunjukkan bahwa ada hubungan positif yang signifikan antara kepuasan kerja, masa kerja dan komitmen keorganisasian. Korelasi positif menunjukkan bahwa semakin tinggi kepuasan kerja dan masa kerja maka akan semakin tinggi komitmen keorganisasiannya. Begitu pula sebaliknya, semakin rendah kepuasan kerja dan masa kerja maka semakin rendah komitmen keorganisasian karyawan.

Komitmen organisasi karyawan dapat dipengaruhi oleh banyak faktor. Kepuasan kerja dan masa kerja karyawan merupakan salah satu faktor yang mempengaruhi. Sebagaimana penelitian yang dilakukan oleh Pratiwi (2006) hasil penelitian ini menunjukkan bahwa ada hubungan positif dan signifikan antara kepuasan kerja, masa kerja dan komitmen organisasi.

Komitmen terhadap organisasi memiliki arti lebih dari keanggotaan formal, karena meliputi sikap menyukai organisasi dan kesediaan untuk mengusahakan ketingkat upaya yang tinggi bagi kepentingan organisasi demi pencapaian tujuan (Steers, 1985). Komitmen individu terhadap organisasi bukanlah merupakan suatu hal yang terjadi secara sepihak, dalam hal ini organisasi dan pegawai (individu) harus secara bersama-sama menciptakan kondisi yang kondusif untuk mencapai komitmen yang dimaksud. Sebagai contoh: seorang pegawai yang semula kurang memiliki komitmen, namun setelah bekerja ternyata selain ia mendapat imbalan sesuai dengan ketentuan yang berlaku ternyata didapati adanya hal-hal yang menarik dan memberinya kepuasan. Hal itu tentu akan memupuk berkembangnya komitmen individu tersebut terhadap organisasi. Apalagi jika tersedia faktor-faktor yang dapat memberikan kesejahteraan hidup atau jaminan keamanan, misalnya ada fasilitas 
transportasi, ada fasilitas yang mendukung kegiatan kerja maka dapat dipastikan ia dapat bekerja dengan penuh semangat, lebih produktif, dan efisien dalam menjalankan tugasnya. Sebaliknya jika iklim organisasi kerja dalam organisasi tersebut kurang menunjang, misalnya fasilitas kurang, hubungan kerja kurang harmonis, jaminan sosial dan keamanan kurang, sikap manajemen diatas mereka yang semaunya, maka secara otomatis komitmen individu terhadap organisasi menjadi makin luntur atau bahkan mungkin ia cenderung menjelek-jelekkan tempat kerjanya.

Hasil analisis terhadap hipotesis minor antara variabel kepuasan kerja dengan komitmen organisasi diperoleh ry1- $2=0,826$ dengan $p=0,000(p \varangle 0,01)$ yang berarti bahwa ada hubungan positif yang signifikan antara kepuasan kerja dengan komitmen organisasi, yang artinya makin positif kepuasan kerja makin tinggi komitmen organisasinya, begitu pula sebaliknya makin negatif kepuasan kerja makin rendah komitmen organisasinya. Ini berarti hipotesis minor pertama pada penelitian ini diterima.

Hasil tersebut senada dengan yang dikatakan oleh Chairy (2002) bahwa kepuasan kerja pada karyawan dapat mempengaruhi tingkat komitmen karyawan terhadap organisasi, dimana semakin tinggi kepuasan kerja karyawan maka semakin tinggi komitmen organisasi pada karyawan. Kepuasan kerja berkaitan dengan proses pemilihan pegawai, terutama berhubungan dengan kebutuhan, kepentingan dan harapan dari para calon pekerja, maka untuk menempatkan orang yang tepat sangat diperlukan (Anorogo dan Widiyanti, 1993). Arifin (1993) menyatakan bahwa kepuasan kerja mempunyai pengertian yang subjektif yaitu setiap orang mendapatkan kepuasan kerja dengan cara-cara yang berbeda. Salami (2008) mendefinisikan kepuasan kerja sebagai keadaan menyenangkan atau keadaan emosi positif yang dihasilkan dari penilaian salah satu pekerjaan atau pengalaman bekerja.

Hipotesis minor kedua, yakni antara variabel masa kerja dengan komitmen organisasi diketahui ry1- $2=0,303$ dengan $p=0,046(p<0,05)$. Hal ini menunjukkan bahwa ada hubungan positif yang signifikan antara masa kerja dengan komitmen organisasi. Berarti makin tinggi masa kerja maka makin tinggi komitmen organisasinya, sebaliknya makin rendah masa kerja makin rendah komitmen organisasinya. Terbuktinya hipotesis minor tersebut menunjukkan bahwa hipotesis minor kedua pada penelitian ini diterima. Variabel masa kerja terhadap komitmen organisasi memiliki sumbangan efektif sebesar $4,9 \%$.

Kepuasan kerja dan komitmen organisasi yang rata-rata tinggi di kalangan karyawan disebabkan pula karena karyawan memiliki rasa aman dan tentram dalam 
bekerja. Karyawan tidak perlu merasa khawatir untuk mencari pekerjaan yang lain (Kuntjoro, 2002). Selain itu masa kerja yang tinggi pada karyawan menunjukkan bahwa karyawan memiliki komitmen yang tinggi pada perusahaan, hal ini seperti hasil penelitian Meiyanto dan Santoso (1999) yaitu semakin lama karyawan bekerja terutama dalam suatu tempat kerja akan merasakan adanya ikatan dengan perusahaan.

Ruang waktu masa kerja yang cukup, sama dengan orang yang telah memiliki pengalaman kerja yang luas, baik hambatan maupun keberhasilannya. M asa kerja yang lama juga akan membentuk pola kerja yang efektif, karena berbagai kendala yang muncul akan dapat dikendalikan berdasarkan pengalamannya, sehingga karyawan yang berpengalaman akan dapat menyelesaikan pekerjaan dengan baik dan dapat mengurangi tingkat turn over yang menyebabkan komitmen pada organisasi rendah (Priyadi, 2009).

Deskripsi data dapat digunakan untuk memberikan gambaran penting mengenai kedaan deskripsi skor skala pada kelompok subjek yang dikenai pengukuran dan berfungsi sebagai informasi mengenai keadaan subjek pada variabel yang diteliti. Skor subjek dalam kelompoknya merupakan estimasi terhadap skor subjek data populasi dan bahwa skor subjek dalam populasinya terdistribusi secara normal. Suatu distribusi normal terbagi atas enam bagian atau enam deviasi standar. Tiga bagian berada disebelah kiri mean (bertanda negatif) dan tiga bagian berada dibagian kanan mean (bertanda positif) (Azwar, 2004). Tujuan dibuatnya katergorisasi adalah untuk menempatkan individu dalam kelompok-kelompok yang terpisah secara berjenjang menurut suatu kontinum berdasar atribut yang diukur (Azwar, 2004, h. 106).

Tabel 1

Deskripsi Skor Skala Komitmen keorganisasian

\begin{tabular}{lll}
\hline & Empirik & Hipotetik \\
\hline Skor maksimm & 88 & 88 \\
Skor minimum & 43 & 22 \\
Rerata & 66,0889 & 55 \\
Standar deviasi & 8,57804 & 14,666 \\
\hline
\end{tabular}

Berdasarkan deskripsi skor subjek dapat diketahui bahwa mean empirik lebih besar dibandingkan dengan mean hipotetik yaitu $66,0889>55$. Artinya bahwa subjek 
penelitian dibandingkan dengan subjek lain dalam populasi yang sama memiliki koitmen organisasi lebih positif. Katergori skor subjek pada skala komitmen keorganisasian berdasarkan kategorisasi dengan distribusi normal kelompok subjek dalam penelitian ini dapat dilihat berdasarkan tabulasi skor kasar aitem penelitian.

Tabel 2

Kategorisasi Skor Skala Komitmen Keorganisasian

\begin{tabular}{llll}
\hline Kategori & Rentang Skor & $\begin{array}{l}\text { Jumlah } \\
\text { Subjek }\end{array}$ & $\%$ \\
\hline Sangat rendah & $22-35,2$ & 0 & 0 \\
Rendah & $36,2-48,4$ & 2 & 4,4 \\
Sedang & $49,4-61,6$ & 9 & 19,9 \\
Tinggi & $62,6-74,8$ & 28 & 62,2 \\
Sangat tinggi & $75,8-88$ & 6 & 13,3 \\
\hline
\end{tabular}

Rentang skor skala komitmen keorganisasian dilihat pada diagram berikut berikut

Diagram 1

Rentang skor skala komitmen keorganisasian

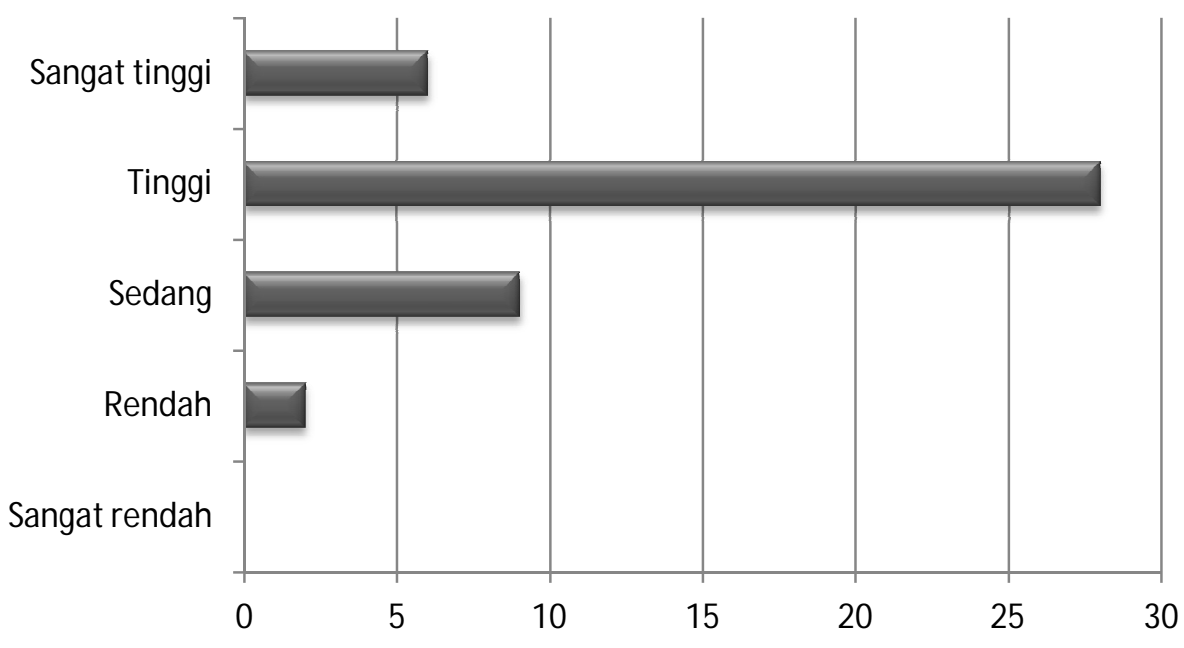


Pada penelitian ini dihasilkan deskripsi skor subjek pada skala kepuasan kerja berdasarkan hasil penelitian (empirik) yaitu skor minimum sebesar 47, skor maksimum sebesar 108, mean empirik sebesar 75,6667 dan standar deviasi empirik sebesar 10,30004. Deskripsi data skala konsep diri dapat dilihat pada tabel berkut :

Tabel 3

Deskripsi data skala kepuasan kerja

\begin{tabular}{lll}
\hline & Empirik & Hipotetik \\
\hline Skor maksimum & 108 & 108 \\
Skor minimum & 47 & 27 \\
Rerata & 75,6667 & 67,5 \\
Standar deviasi & 10,30004 & 18 \\
\hline
\end{tabular}

Kategorisasi skor subjek pada skala konsep diri berdasarkan kategorisasi dengan distribusi normal kolompok subjek dalam penelitian ini dapat dilihat berdasarkan tabulasi skor kasar aitem valid. Jumlah subjek penelitian pada skala kepuasan kerja yang masuk dalam kategori skor dapat dilihat pada tabel berikut:

Tabel 4

Kategori skor kepuasan kerja

\begin{tabular}{llll}
\hline Kategori & Rentang Skor & $\begin{array}{l}\text { Jumlah } \\
\text { Subjek }\end{array}$ & $\%$ \\
\hline Sangat rendah & $27-43,2$ & 0 & 0 \\
Rendah & $44,2-63,4$ & 2 & 11,1 \\
Sedang & $64,4-78,6$ & 27 & 53,2 \\
Tinggi & $79,6-94,8$ & 13 & 28,8 \\
Sangat tinggi & $95,8-108$ & 3 & 6,6 \\
\hline
\end{tabular}


Rentang skor skala konsep diri dilihat pada diagram berikut berikut :

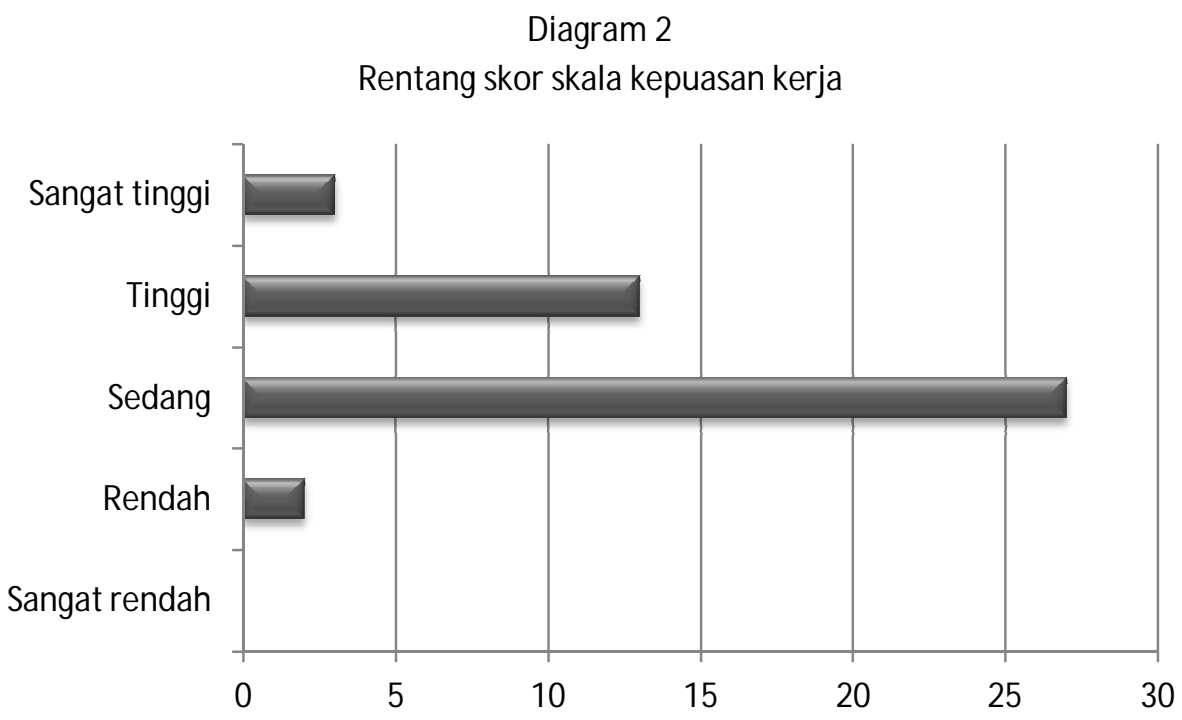

\section{Kesimpulan Dan Implikasi Penelitian}

Berdasarkan hasil penelitian dan pembahasan terhadap hasil penelitian, maka dapat ditarik kesimpulan sebagi berikut: (a). Ada hubungan yang signifikan antara kepuasan kerja, masa kerja dengan komitmen organisasi karyawan PT. Royal Korindah Purbalingga; (b). Ada hubungan positif yang signifikan antara kepuasan kerja dengan komitmen organisasi karyawan PT. Royal Korindah Purbalingga. Semakin tinggi kepuasan kerja maka makin tinggi komitmen organisasinya, begitu pula sebaliknya makin rendah kepuasan kerja maka makin rendah komitmen organisasinya; (c). Ada hubungan positif yang signifikan antara masa kerja dengan komitmen organisasi karyawan PT. Royal Korindah Purbalingga. Semakin tinggi masa kerja maka makin tinggi pula komitmen organisasinya, sebaliknya makin rendah masa kerja maka makin rendah komitmen organisasinya.

Adanya hubungan yang sangat signifikan antara kepuasan kerja, masa kerja dengan komitmen organisasi menunjukkan bahwa aspek-aspek kepuasan kerja seperti aspek psikologik, aspek sosial, aspek fisik, dan aspek finansial menentukan komitmen organisasi dengan sumbangan efektif sebesar $65,9 \%$ dan sumbangan efektif masa kerja 
sebesar 4,9\%. Perusahaan perlu mempertahankan dan meningkatkan komitmen pegawai agar bisa lebih baik lagi dengan selalu berupaya memperbaiki programprogram yang dapat meningkatkan kepuasan kerja karyawan misalnya: menciptakan suasana kerja yang baik, besarnya gaji, promosi, kondisi lingkungan kerja dan lain-lain dalam rangka memberikan konstribusi bagi kemajuan perusahaan. Hasil penelitian menunjukkan bahwa subjek penelitian memiliki kepuasan kerja, masa kerja dan komitmen organisasi yang tinggi. Oleh karena itu para karyawan diharapkan untuk tetap mempertahankan dan meningkatkan komitmennya terhadap perusahaan, yaitu dengan meningkatkan diri dalam karir dan bersikap positif terhadap kebijakankebijakan perusahaan.

Bagi Peneliti Selanjutnya, berdasarkan hasil penelitian maka, peneliti menyarankan agar peneliti selanjutnya menyebarkan alat ukur penelitian secara langsung sehingga dapat mengobservasi langsung keadaan dan kondisi subjek penelitian. Bagi peneliti selanjutnya yang ingin melakukan penelitian sejenis disarankan untuk memperhatikan faktor lain yang mungkin berpengaruh terhadap komitmen organisasi pada karyawan misalnya: iklim psikologis, identifikasi dan keterlibatan kerja ataupun faktor-faktor lain (iklim organisasi, waktu kerja sifat dan variasi pekerjaan, pendidikan, usia, jenis kelamin dan status perkawinan) yang bisa mempengaruhi komitmen organisasi.

\section{Daftar Pustaka}

Aamodt, M. G. (2004). Applied Industrial/Organizational Psycology $4^{\text {th }}$ Ed. Belmont, California: Wodsworth/ Thomson Learning.

Anorogo. P dan Widiyanti. N. (1993). Psikologi Dalam Perusahaan. Jakarta: PT Rineka Cipta.

Arifin, Z. (1993). Hubungan Diantara Tekanan dan Kepuasan Kerja Di kalangan Pekerja. Majalah Psikologi. Bil 13; 103-121.

Arikunto, S. (2002). Prosedur Penelitian Suatu Pendekatan Praktek, Ed. Revisi. Jakarta: Rineko Cipta.

As'ad, M. (2004). Psikologi Industri. Yogyakarta: PT Liberty.

Azwar, S . (2003b). Reliabilitas dan Validitas. Yogyakarta: Pustaka Pelajar.

Chairy, S. L. (2002). Seputar Komitmen Organisasi. Jakarta: Fakultas Psikologi Universitas Indonesia. 
Davis, K \& Newstrom, J. W. (1994). Perilaku dalam Organisasi. Jilid 1. Alih Bahasa: Agus Dharma. Jakarta: Penerbit Erlangga.

Doraisamy. (2007). Hubungan Tekanan Kerja dan Kepuasan Kerja dengan Komitman terhadap Organisasi: Satu kajian di Ibu Pejabat Jabatan Kerja Raya Malaysia. Sintok Kedah Darul Aman: Universiti Utara M alaysia.

Febriani, L. S. (2004). Hubungan antara Kepuasan Kerja dan Keterlibatan Kerja dengan Komitmen Organisasi pada Karyawan PT. Astra International Tbk-Isuzu Cabang Semarang. Skripsi (tidak diterbitkan). Semarang: Fakultas Psikologi Universitas Katolik Soegijapranata.

Fauzan, R. (2009). Komitmen Berorganisasi. http://ipo.lab.uii.ac.id/index.php? Option=comcontent\&task=view\&id=15\&itemid=27. M onday, 15 June 2009.

Hadi, S. (2001a). Metodologi Research Jilid 3. Yogyakarta: Andi.

. (2001b). Isu-isu Uji Asumsi. Buletin Psikologi, Tahun IX, No.1, Hal. 2-3

Kuntjoro, Z S. (2002). Komitmen Organisasi (makalah) from http://www.epsikologi.com/masalah/250702.htm. Desember 2005.

Luthans, F. (1998). Organisasi Behavior. $8^{\text {th }}$ edition. New York: M c Graw-Hill. . (1995). Jurnal Manajemen, Jurnal M anajemen Sumber Daya Manusia, Bahan Kuliah Manajemen. M embangun Komitmen Organisasi. http://jurnalsdm.blogspot.com/2009/04/membangun-komitmen-organisasi.html

Murtiningtyas, L. (2007). Komitmen Kerja Perawat Laki-laki Dikaitkan dengan Persepsi terhadap Pembedaan Gender. Skripsi (tidak diterbitkan). Semarang: Fakultas Psikologi Universitas Katolik Soegijapranata.

Martini, Y. dan Rostiana. (2003). Komitmen Organisasi Ditinjau Berdasarkan Iklim Organisasi dan M otivasi Berprestasi. Phronesis. Jakarta. 5. (9); 21-31.

Meiyanto, S. dan Santoso, F. H. (1999). Nilai-nilai Kerja dan Komitmen Organisasi: Sebuah Studi dalam Konteks Pekerja Indonesia. Jurnal Psikologi. 1; 29-40.

Oktafiyani, Y. (2009). Pengaruh Pendidikan dan Masa Kerja Terhadap Kedisiplinan Karyawan di SMK Muhammadiyah Surakarta. Skripsi (tidak diterbitkan). Surakarta: Fakultas Keguruan dan IImu Pendidikan Universitas Muhammadiyah Surakarta.

Pratiwi, A. A. (2006). Hubungan Kepuasan Kerja, Masa Kerja dan Komitmen Organisasi pada Karyawan Sekretariat Pemerintahan Kabupaten Malang. Skripsi. Malang: Fakultas IImu Pendidikan, Universitas Negeri M alang. 
Priyadi. (2009). Pengaruh Umur, Masa Kerja dan Gaya Kepemimpinan terhadap Kinerja Karyawan PT. M ondrian Klaten. Skripsi (tidak diterbitkan). Surakarata: Fakultas Ekonomi Universitas M uhamadiyah Surakarta.

Salami, S. O. (2008). Demographic and Psychological Factors Predicting Organizational Commitment Among Industrial Workers. Anthropologist. 10. (1); 31-38.

Seniati, L. (2006). Pengaruh Masa Kerja, Trait Kebaikan Hati, dan Kepuasan Kerja dan Iklim Organisasi terhadap Komitmen Dosen pada Universitas Indonesia. Makara, Sosial Humaniora. Vol. 10. (2); 88-97.

Setyowati, A. (2005). Komitmen Organisasi Ditinjau dari Persepsi Terhadap Program Pelatihan Tenaga Kerja dan Masa Kerja. Skripsi (tidak diterbitkan). Semarang: Fakultas Psikologi Universitas Katolik Soegijapranata.

Shirbagi, N. (2007). Exploring Organizational Commitment and Leadership Frames Eksploring Within Indian and Iranian Higher Education Institution. Bulletin of Education \& Researc. 29. (1); 17-32.

Simamora, H. (1995). Manajemen Sumber Daya Manusia. Yogyakarta: STIE YKPN.

Steers, R. M. (1985). Komitmen Organisasi. http://www.pasamankab.go.id/ index.php/artikel/48-kepemimpinan/236-komitmen-organisasi.html. Jumat, 15 M aret 2010.

Sulianti, D. K. L. (2009). Pengaruh Komitmen Organisasi dan Kepuasan Kerja terhadap Kinerja Karyawan PT. Perkebunan Nusantara III di Sumatra Utara. Jurnal Manajemen dan Kewirausahaan. 11. (1); 31-37.

Winarta. (2007). Pengaruh Kepuasan Kerja pada komitmen Organisasi dengan Usia dan M asa Kerja sebagai Variabel Pemoderasi (Studi pada SMK Kristen 2 Surakarta). http://www.mitrariset.com/abstrakpdf-7493/koleksi-40.html. 